UDC 94(477.8) «1921-1939»

DOI: 10.24919/2519-058X.10.159181

\title{
Irina SKAKALSKA
}

PhD hab. (History), Professor, Department of Ukrainian Philology and Publik Disciplines, Taras Shevchenko Kremenets Regional Academy, 36 Makova Street, Kremenets, Ukraine, postal code47003 (irunas@ukr.net)

ORCID: $h$ htps://orcid.org/0000-0001-8705-7971

ResearcherID: B-9391-2019 (http://www.researcherid.com/rid/B-9391-2019)

\section{Inna SEMENETS-ORLOVA}

PhD hab. (Public Administration), Associate Professor, Department of Sociology and Politology, National Aviation University, 1 Kosmonavta Komarova ave, Building 8, Kyiv, Ukraine, postal code 03058 (innaorlova@ukr.net)

ORCID: https://orcid.org/0000-0001-9227-7426

ResearcherID: G-3956-2017 (http://www.researcherid.com/rid/G-3956-2017) Scopus Author ID: 57204214125 (https://www.scopus.com/authid/detail.uri?authorId=57204214125)

\section{Ірина СКАКАЛЬСЬКА}

доктор історичних наук, професор кафедри украӥнської філологї̈ і суспільних дисииплін Кременеиької обласної гуманітарно-педагогічної академї ім. Тараса Шевченка, вулиия Макова, 36, м. Кременець, Україна, 47003 (irunas@ukr.net)

\section{Інна СЕМЕНЕЦЬ-ОРЛОВА}

доктор наук з державного управління, дочент кафедри сочіології та політології Національного авіаційного університету, просп. Космонавта Комарова, 1, м. Kü̈в, 03058, Україна (innaorlova@ukr.net)

Бібліографічний опис статті: Skakalska, I., \& Semenets-Orlova, I. (2019). The Ukrainian elite of Western Volhynia (1921 - 1939): sources of the research problem. Skhidnoievropeiskyi Istorychnyi Visnyk [East European Historical Bulletin], 10, 141-148. doi: 10.24919/2519-058X.10.159181

\section{THE UKRAINIAN ELITE OF WESTERN VOLHYNIA (1921 - 1939): SOURCES OF THE RESEARCH PROBLEM}

Summary. The purpose of the research is to analyze and summarize certain archival and published sources, which contain information on the activities of the Ukrainian elite of Western Volhynia in the interwar period of the XX century. The research methodology is based on regionalist approaches to studying the problem. In the course of the study, general scientific methods were used. First of all, the method of actual data collecting (accumulation of facts) and the method of actual data compiling (analysis) were applied. Also, special methods (biographical, prosopographical, source study analysis) were used to characterize the activities of the Volhynian elite. During the study, a critical method was used, the value of which is a demanding approach to any information until it passes through the research verification. This method has been used most expediently during memoirs handling. The «text era» method is also important. The research novelty is based on outlining the available sources on 
the history of the Ukrainian Volhynian elite. It is also extended the methodological capabilities understanding of the biographical method in the research of the elite on the source materials basis. An analysis of the saved data about the Volhynian elite has been carried out, since the available sources are not a comprehensive list of possible ones, and further unknown data may be opened at further study. Conclusions. During 1921 - 1939 the Ukrainian elite of Western Volhynia played a significant role in the history of the region. The materials of the Polish authorities, party documents and the Ukrainian parliamentary representation in Volyn, as well as personal founds of public and political figures have the primary importance for the study of the Ukrainian elite activities of the interwar period in Poland. The source base is also compiled by a few contemporary memoirs of the events under study. The source study analysis of the research problem confirms that the information base of the research is rather extensive and varied. The representativeness and degree of reliability of materials are determined. A comprehensive and impartial approach to the whole set of documents enables to carry out a research analysis of ethno cultural transformation and socio political dimension among the Ukrainian elite of Western Volhynia in the interwar period of the XX century. The wide source base contributes to the deepening and coverage of various aspects of the ethnic population life of the region and the Ukrainian elite in the force field of the existing Polish government, which embodied the policy of assimilation in the Volyn lands. The comprehensive analysis of archival documents allows us to elaborate on a number of issues that are still not fully considered in Ukrainian historiography.

Key words: Western Volhynia, sources, the elite, documents, memoirs, Kremenets powiat, archeography.

\section{УКРАЇНСЬКА ЕЛІТА ЗАХІДНОЇ ВОЛИНІ (1921 - 1939): ДЖЕРЕЛЬНА БАЗА НАУКОВОЇ ПРОБЛЕМИ}

Анотація. Мета дослідження - аналіз окремих архівних та опублікованих джерел, у яких міститься інформація про діяльність української еліти Західної Волині у міжвоєнний період ХХ ст. Методологія дослідження спирається на регіоналістичні підходи до вивчення проблеми. У ході дослідження використовувалися загальнонаукові методи, насамперед збирання фактичних даних (нагромадження фактів) $і$ їх компонування (аналізу). Також було застосовано спеціальні методи (біографічний, просопографічний, джерелознавчого аналізу), які допомагають схарактеризувати діяльність волинської еліти. Під час дослідження послуговувалися критичним методом, значення якого полягає у вимогливому ставленні до будь-якої інформації доти, доки вона не пройде через дослідницьку верифікацію. Найбільш доиільно цей метод було використано під час опраиювання мемуарів. Важливим є метод «текстової епохи». Наукова новизна полягає в окреслені наявних джерел з історії украӥнської волинської еліти. Поглиблено розуміння методологічних можливостей біографічного методу в дослідженні еліти на основі джерельних матеріалів. Здійснено аналіз збережених даних про волинську еліту. Оскільки наявні джерела не є вичерпним переліком тих, щүо, можливо існують при подальшому вивченні можуть відкритися досі невідомі. Висновки. Украйнська еліта Західної Волині у 1921 - 1939 рр. відіграла вагому роль в історії краю. У наявній сукупності друкована і неопублікована частини наявної джерельної бази є досить репрезентативною і дає можливість досліджувати проблеми формування і праці украӥнської еліти.

Першочергову вагу для дослідження діяльності украӥнської еліти міжвоєнного періоду у Польщі мають матеріли органів влади, документи партій та Украйнської парламентської репрезентації на Волині, а також персональні фонди громадських і політичних діячів тощо. Дюерельну базу складають також нечисленні мемуари сучасників досліджуваних подій.

Проведений джерелознавчий аналіз досліджуваної проблеми підтверджує, що джерельна база дослідження є доволі обширною та різноманітною. Визначена репрезентативність та ступінь достовірності матеріалів. Широка джерельна база сприяє поглибленню і висвітленню по-новому різноманітних сторін життя етнічного населення краю та украӥнської еліти в силовому полі існуючого польського режиму, який на волинських землях втілював політику асиміляиії. Комплексний аналіз архівних документів дає змогу докладніше окреслити коло питань, які досі в украӥнській історіографії розглядались не в повному обсязі. Запровадження до наукового обігу нових джерел сприятиме висвітленню трансформації еліти в іншому ракурсі.

Ключові слова: Західна Волинь, джерела, еліта, документи, спогади, часописи. 
Problem statement. The formation of the Ukrainian elite is an important problem nowadays because the ideological transformation of society in Ukraine should be spread by a population stratum that would combine intelligence, spirituality, and patriotism. The state needs its own national elite, which is professionally responsible. History shows that elite creative processes are long-term, as well as the past and the present are closely interconnected. Accordingly, one of the models for imitation can be formation and activity o of the Ukrainian elite of Western Volhynia in the interwar period of the XX century. In order to outline the multifaceted activity of the Ukrainian elite of Western Volhynia in the interwar period of the $\mathrm{XX}$ century thoroughly, it is necessary to characterize the existing source base, to highlight the most important documents and materials.

The analysis of sources and recent researches. Comprehensive scientific analysis of the sources related to the activity research of the Ukrainian elite of Western Volhynia in the interwar period of the XX century was not carried out by researchers. In the publication Memoirs of Yu. Shumovskyi as a source from the history of the Volhynian spiritual intelligentsia of the first half of the XX century (Skakalska, 2010) instead of characterizing holistically all available and known sources, the author characterizes only one aspect of the problem. An example of such researches is the introductory part of Professor M. Kucherepa to the published memoirs of the Volhynian governor Henryk Józewski (Yuzevskyi, 2017). Also, the researcher V. Korniienko analyzes the memoirs of the elite representatives of the early XX century, but on the subject of the patriotic beliefs presence (Korniienko, 2016, p. 281-282).

The purpose of the article is to analyze and summarize certain archival and published sources, which contain information on the activities of the Ukrainian elite of Western Volhynia in the interwar period of the XX century.

Statement of the basic material. According to the Peace of Riga of 1921, Volhynia was divided artificially. The eastern part of its territory went to the USSR, and the western part was included in the Polish Republic as its integral part. Volhynian Voivodeship, with its center in Lutsk, was established on the territory of Western Volhynia. At this time, the bourgeoisie, teachers, doctors, artists and clergy were members of the Ukrainian intelligentsia that was not numerous. In addition, many of them were immigrants from Dnieper Ukraine and had the experience of struggle for Ukrainian statehood. They became leaders of political parties, public associations, and presenters of national revival ideas.

The Polish authorities implemented a policy of assimilation and discrimination against national minorities, in particular Ukrainians. The persecution and repression against the Ukrainian elite are evidenced by the materials of the State Archives of Brest Region (Belarus), the fonds 98 «Bereza Kartuska Detention Camp». It is known that a lot of representatives of the national elite were there because of their political beliefs.

The Ukrainian elite recorded events in Western Volhynia and expressed their views on solving individual problems concerning religious and social aspects of life. Thus, the personal files of the Ukrainian intelligentsia who worked in Volhynia and forced to emigrate to other countries are kept in the Central State Archives of Supreme Bodies of Power and Government of Ukraine. The fonds P-4465 «Collection of Separate Documentary Materials of Ukrainian Nationalist Emigrant Institutions, Organizations and Individuals» contains works of the Volhynian intelligentsia. Only works by R. Bzheskyi, V. Bidnov, U. Samchuk are stored in handwritten form.

There is relatively little information on the Volhynian elite activities of the XX century in the fonds of the Central State Historical Archives of Ukraine in Lviv. In particular, separate documents of the fonds 348 «Prosvita Society» confirms the public potential of the Volhynian elite. Another fonds - 392 «Ukrainian Parliamentary Representation in the Polish Sejm and the Senate» contains some information about political activities of the elite, its participation in the elections to the Polish parliament. The fonds 351 «Ukrainian Peasant Worker Union, Lviv» enhances information about political activities of the elite. 
The fonds of the State Archives of the Volyn Region are of particular scientific interest. The fonds 46 «Volyn Voivodeship Directorate» reveals the transformation of the Volyn elite between two world wars in Western Volhynia. Among the issues of the fonds there are materials that show public and political activities of leading figures of the region in separate powiats (counties). The reports on the activities of civic organizations, the letters to the leaders of the socities, the report of elderships on the elections passing to the Sejm, etc. are important. For the study of the spiritual stratum, the personal cases of religious figures are of great importance, in particular, the case 2668 «Service Case of the Priest Maliuzhynskyi Mykola», located in the fonds 46

The fonds 200 «Volyn Ukrainian Theater Society» is valuable for the artistic environment reproduction of the Ukrainian cultural elite. In the fonds 60 «Ukrainian Parliamentary Representation in Volyn», there is an informative case 11 «Articles, Reports and Speeches of Ambassador Serhii Kozytskyi (1926 - 1927)». The fonds 522 «The Lawyer Hryhorii Stepura in Lutsk» should also be noted. Substantive materials for studying the problem are found in the fonds 63 «Lutsk Administration of the Orthodox Supporters and the Protection of the Orthodoxy Traditions named after Petro Mohyla Society», for example, case 13 «The Report on the Society Activities for the Period from 02 April 1933 to 09 October 1936». The fonds 389 «Kovel Powiat Prosvita Society» contributes to a more comprehensive disclosure of the national elite public activities.

Separate sources of the identified problem are stored in the fonds of the State Archives of Zhytomyr Region, in particular, materials from the fonds 1 «Volyn Spiritual Consistory» allowed to supplement the biographical data of B. Kozubskyi, a lawyer, enlightener and ambassador of the Sejm. Also the fonds 560 «Volyn Enlightenment Society», case 4, clarifies the biography of the famous Senator O. Levchanivska.

The fonds of the State Archives of Rivne Region served as a significant source for characterizing the Ukrainian leading stratum. The fonds 30 «Rivne Powiat Starostwo» contains separate materials on this issue. In the fonds 160 «Jakub Hoffman», who was a historian and ethnographer, deputy of the Polish Sejm, the subject of a thorough analysis became the case 17 «The Charter of the Discussion Club of Ambassadors and Senators, the Draft Statute of the Parliamentary Cultural and Educational Group of Ambassadors and Senators», as well as documents related to the functioning of Volyn Scientific Institute at the Kremenets Lyceum, the verbatim recordings of Jakub Hoffman's performances in the Sejm of 1937 - 1938, and others. The fonds 265 «The 60th Electoral District for Elections to the Sejm of 1938» contains protocols of election commissions meetings. The fonds 33 «Prosecutor's Office of the Rivne District Court» provides an opportunity to observe the political activities of the national elite. The materials of the fonds 86 «Rivne District Administration of the State Police» are of a great value.

Most of the cases on this issue are contained in the fonds of the State Archives of Ternopil Region. For the most part it is the fonds 2 «Kremenets Powiat Starostwo», for example, where some cases are introduced to scientific circles for the first time. This is the case 1406 «The Statute and the Request for Registration of the Professional Union of Industrial Workers Society in Vyshnevets Village», the case 1154 «The Request of the Inhabitants and the Commune Governor's Chamber on the Reduction of Night-time Protection in the Village», the case 1408 «The Statute and Periodical Information Regarding the Union of Village Housewives Society in Losiatyn village. 1936». The following fonds are also informative for us: the fonds 134 «Kremenets City Government of Volyn Voivodeship», the fonds 148 «Volyn Orthodox Spiritual Consistory», the fonds 222 «Kremenets District School Inspectorate», the fonds 231 «Political Parties of Kremenets District», the fonds 232 «Kremenets Orthodox Theological Seminary of the Volyn Voivodeship» (in this fonds we meet the personal cases of future religious leaders - the case 274 «Special Case of Yu. Shumovskyi»), the 
fonds 316 «Kremenets District Police» (many documents of this fonds require a particularly critical attitude). The study of these sources helps to disclose adequately all areas of political, social and ethno cultural transformation of the Ukrainian elite of Western Volhynia. For studying the issues considered in this research, the fonds 348 «The Prosvita Society» is of great importance. It contains protocols, letters of association and information about famous enlighteners. In the process of studying the documents of the fonds 351 «Kremenets Ukrainian Gymnasium», it was found that educational institutions were an important source of the national elite replenishment, first of all, the Ukrainian private gymnasium in Kremenets. A large number of documents were involved for the first time from this fonds. The materials are considered in details, where the information about teachers and pupils is presented. The fonds 228 «Kremenets State Gymnasium named after Chatskyi» contains the information about the educational elite. It should be emphasized that a large part of materials related to the activities of the spiritual elite is included in the fonds 258 «Spiritual Cathedral of the Pochayiv Lavra». A large number of documents from this fonds are used for the first time.

Thus, the complex of the archival sources discovered by us is significant; it contains important data that allow a much more complete coverage of the activities of the Western Volhynia national elite during $1921-1939$.

A number of sources are stored in the fonds collection of the Kremenets Regional Museum. For example, information about the activities of O. Tsynkalovskyi or materials of the Volyn Institute of Science. This was the name of the institution that operated at the Kremenets Lyceum during 1938 - 1939 and was involved in conducting regional studies and scientific work. Some details of the research problem can be found in the regional studies of the interwar period, which are presented by Polish magazines and publications such as Rocznik Wotyński (vol. 3, ed. J. Hoffman, Rivne, 1934); Województwo Wotyńskie w świetle liczb $i$ faktów (Lutsk, 1929); Źycie krzemienieckie (1932 - 1933); Przewodnik po Kpzemieńcu i okolicy (Kremenets, 1932); Przewodnik po województwie Tarnopolskiem (z mapa) (Krakow, 1928); J. Hoffman Przewodnik po Wotyniu (Warszawa, 1938). Separate copies are stored in the museum, as well as in private collections of Kremets citizens.

Among published documents it is necessary to distinguish the Branch State Archive of the Security Service of Ukraine, the fonds 65, the case C-9134, devoted to the activities of Taras Bulba-Borovets, whose views and ideological convictions were formed precisely in Western Volhynia in the interwar period of the XX century. (Serhiichuk, 2011, p. 29).

The collection Ukraine and Poland: Documents and Materials of 1920 - 1939, published in 2012, is a significant contribution to the restoration of the Ukrainian elite in the historical situation conditions of that time in Volyn in the area of interstate diplomatic relations between the USSR and the Second Polish-Lithuanian Commonwealth (Rublova \& Rublov, 2012). The extensive archival material used by the compilers allows for a careful coverage of the Soviet and Polish authorities policy regarding the situation in the Volhynian lands. The collection consists of 133 documents from the fonds of the Central State Archives of the Supreme Authorities and Governments of Ukraine, the Central State Archives of Public Associations of Ukraine, the Branch State Archive of the Security Service of Ukraine and its regional subdivisions.

In the process of our research, attention is paid to published documents from the Archives of New Files (Warsaw) (Syvitskyi, 2005). Also, a collection of materials «Our Beautiful Generation...» (Volyn in the fate of the countrymen and human documents), compiled by L. Oliander, L. Bubleinyk, M. Kucherepa (published in Lutsk in 1996), contains documents, memoirs that reveal the history of the Volhynian elite.

The important materials for outlining the sources are sought in the periodical journal The Church and the Nation, which was published in Kremenets, Volyn Voivodeship in 1935 - 1936 (edited by Ivan Vlasovskyi). This publication contains various publications, 
research on different issues, etc. The content of the journal was divided into two sections: informal (words and sermons, apologetic articles, church history and archeology, church journalistic articles, stories, poems, political life, in the press, chronicles, obituaries, and writings) and formal (the order of the diocesan authority, decisions, statutes, reports, etc.). The journal The Church and the Nation is a peculiar and multifaceted historical source, not only in terms of content, but also in terms of the structure of published factual material. The information on the activities of the Ukrainian elite of Volyn was published here. Numerous notes, articles that are intensified with historical, religious, literary information, reflect the activities of leading Ukrainians in the region. However, journal publications are lack of clear reflection of the Ukrainian intelligentsia participation in the national liberation movement in Volyn of the interwar period, its work in societies and organizations.

In addition to the above mentioned periodic sources, it is necessary to name the non-periodic journal of the Society named after Petro Mohyla For the Unification, published in Lutsk, which placed materials of a religious orientation. It printed the scientific researches of V. Bidnov (Volyn in the Orthodox Church Defense in the XVI-XVII centuries), I. Vlasovskyi (The Church Reform and Clergy) and other representatives of the Ukrainian elite of Western Volhynia in the interwar period of the XX century.

Narrative sources are memoirs, nonfiction of famous political and public figures (Yu. Shumovskyi, V. Karhut, M. Skakalskyi, R. Hluvko, H. Yuzevskyi, etc.). These sources help to understand the historical period better. Actually, the historian is a kind of translator, who must understand the «language» that is spoken by the source; he should know the meaning of the concepts that were in the heads of the people of the past (Yakovenko). The memoirs reveal the life of the contemporary elite.

The memoirs The Ruined Nest, or the History of a Priestly Family in Volhynia by Yurii Shumovskyi (an archaeologist, Orthodox priest), written in the late XX century, is an important source for studying the history, archeology, culture, religion and various spheres of life of the Volyn people. They are valuable for studying various aspects of socio political and national cultural development of society. He mentions the names of well-known figures he met or faced with their activities. A copy of the memoirs is kept in the premises of the Kremenets district Prosvita society and is waiting for a thoughtful researcher.

The unique memoirs with a large amount of illustrative material are the recordings of Musii Skakalskyi, a resident of Kremenets (Skakalskyi). They contain information about the elections to the Polish Sejm, the development of the economic life of the region, the culture of Volhynia, the well-known people. A native of Western Volhynia, a famous artist, an icon painter R. Hluvko also left memoirs of the land where he was born and raised (Hluvko, 2003). The diary of the Volyn governor Henryk Józewski is a view of the official on the Ukrainian elite (Yuzevckyi, 2017).

It should be noted that a certain array of sources from the history of the Ukrainian elite of Western Volhynia was outside Ukraine. Winnipeg in Canada became a well-known Ukrainian community center. The Volyn Institute of Experiments and the Volyn Society, which united the intellectual elite came from Volyn, were founded there. The publication of memoirs in The Chronicle of Volhynia, which was published in Canada, for example (Melnyk, 1988), allowed the Ukrainian archeology to attract a powerful array of sources from the diaspora to scientific use.

There are cognitive memoirs of an emigrant Yakov Lavrychenko, a former enlightenment and cooperative figure of the interwar period, a native of the Popivtsi village, Kremenets district of Volyn Voivodeship. For example, in his research, we find information about Ukrainian officials, but only the lowest levels of Polish power. In particular, he talks about M. Swiderskyi, the woyt of Pochayiv commune of the Kremenets district, as «an honest person, an intellectual and an economist» (Lavrychenko, p. 23). 
In order to understand the political beliefs of the Ukrainian elite, it is necessary to get acquainted with their works on this topic, for example, by Senator M. Cherkavskyi (Cherkavskyi, 1927). Party program documents also cover one of the directions of the elite's work. A contemporary historian Z. Porai substantiated the correctness of the UNDA policy (Ukrainian National Democratic Association) regarding the participation of the Ukrainian elite in the parliamentary elections of 1938, which were boycotted by the majority of Ukrainian political forces (Porai, 1938). Also, tasks and the purpose of the USRP (Ukrainian Socialist Radical Party) were set out in the political program What Does the USRP Want?, which in its turn is the conviction and practical activity of the part of the elite that supported the ideology of the party.

The press provided information on the scientific work of the elite, but it was extremely laconic and designed for the mass reader (Feshchenko-Chopivskyi, 1938, p. 373). The scientific articles of I. Vlasovskyi, who was a notable figure in Volyn in the interwar period of the XX century, were published in periodicals (Vlasovskyi, 1938, p. 20-25). The scientific achievements of the Ukrainian elite were not significant, since there were no relevant national scientific institutions or higher educational institutions in Volhynia.

Separately, it is necessary to highlight autobiographical journalistic works considered critically by us, since they contain a significant percentage and artistic imagination of the author. But we could not refuse such sources. Because such works are informative; their creators are the representatives of the Ukrainian elite. The publicist story with autobiography elements Flaming Whirlwind written by a doctor, a public figure V. Karkhut, presents the names of well-known representatives of the national elite of Volhynia, reveals the life peculiarities of Kremenets citizens in the Volyn Voivodeship (Karkhut, 2003). It is worth paying attention to the autobiographical work of a famous writer U. Samchuk The Youth of Vasyl Sheremeta, which reveals the formation conditions of the national elite of Volhynia, and shows the role played in this process by the Kremenets Ukrainian private gymnasium where he studied (Samchuk, 2005).

Conclusions. We can affirm that the complex of printed and unpublished parts of the existing sources is quite representative and allows us to research the source problems of formation and work of the Ukrainian elite.

The materials of the Polish authorities, party documents and the Ukrainian parliamentary representation in Volyn, as well as personal founds of public and political figures have the primary importance for the study of the Ukrainian elite activities of the interwar period in Poland. The source base is also compiled by a few contemporary memoirs of the events under study.

The source study analysis of the research problem confirms that the information base of the research is rather extensive and varied. The representativeness and degree of reliability of materials are determined. A comprehensive and impartial approach to the whole set of documents enables to carry out a research analysis of ethno cultural transformation and socio political dimension among the Ukrainian elite of Western Volhynia in the interwar period of the XX century.

The wide source base contributes to the deepening and coverage of various aspects of the ethnic population life of the region and the Ukrainian elite in the force field of the existing Polish government, which embodied the policy of assimilation in the Volyn lands. The comprehensive analysis of archival documents allows us to elaborate on a number of issues that are still not fully considered in Ukrainian historiography.

Acknowledgments. The authors of the publication express the sincere gratitude to the Professor Afanasii Lomakovych - rector Taras Shevchenko Kremenets Regional Academy.

Funding. The authors received no financial support for the research, authorship, and/or publication of this article. 


\section{BYBLIOGRAHY}

Avtor nevidomyi. (1938). Vidchyt prof. I. Feshchenka-Chopivskoho [Professor's speech I. Feshchenko-Chopovsky]. Tserkva i narid, 8-9, 373. [in Ukrainian].

Vlasovskyi, I. (1938). Novi metody navchannia i nauka relihii v shkoli. [New methods of teaching and science of religion at school]. Tserkva i narid, 6, 20-25. [in Ukrainian].

Hluvko, R. (2003). Memorabilia: Spomyny. [Memorabilia]. (Perekl. z anhl. movy Marii Yatsiv). Lviv: Afisha, 176 p. [in Ukrainian].

Karkhut, V. (2003). Polum'ianyi vykhor [Fiery whirlwind]. Ivano-Frankivsk: Lileia-NV, 128 p. [in Ukrainian].

Korniienko, K. (2016). Ukrainska elita i patriotyzm pochatku XX st. [The Ukrainian elite and patriotism of the early XX century]. Zapysky istorychnoho fakultetu Odeskoho natsionalnoho universytetu, 27, 280-285. doi: https://doi.org/10.18524/2312-6825.2016.27.105835 [in Ukrainian].

Melnyk, T. (1988). Lanivtsi (Spomyny). [Lanovci (Pomini)]. Litopys Volyni, 15, 56-60. [in Ukrainian].

Lavrychenko, Ya. (1988). Velyka Volyn mizh dvoma viinamy. [Great Volyn between two wars]. Litopys Volyni, 15, 8-39. [in Ukrainian].

Porai, Z. (1938). Idemo do vyboriv. [We go to the elections]. Lviv: Vydannia UNDO, $40 \mathrm{p}$. [in Ukrainian].

Samchuk, U. (2005). Yunist Vasylia Sheremety. [Youth of Vasyl Sheremety]. Rivne: Volynski oberehy, 328 p. [in Ukrainian].

Serhiichuk, V. (2011). Derzhavnyi arkhiv Sluzhby bezpeky Ukrainy, f. 65, spr. S-9134, t.4, ark. 19. In Taras Bulba-Borovets Dokumenty. Statti. Lysty. [Taras Bulba-Borovets Documents. Articles. Letters]. (Za zah. red. V. Serhiichuka). Kyiv: PP Serhiichuk M. I., 29. [in Ukrainian].

Syvitskyi, M. (2005). Istoriia polsko-ukrainskykh konfliktiv [History of Polish-Ukrainian conflicts]. (Per. z pol. Ye. Petrenka). Kyiv: Vydavnytstvo imeni Oleny Telihy, 344 p. [in Ukrainian].

Skakalska, I. (2010). Spohady Yu. Shumovskoho yak dzherelo z istorii diialnosti dukhovnoi intelihentsii Volyni pershoi polovyny XX st. [The guards of Yu. Shumovsky as a source of the history of the spiritual intelligentsia of Volyn in the first half of the twentieth century]. «Aktualni problemy vitchyznianoi ta vsesvitnoi istorii»: Rivnenskyi derzhavnyi humanitarnyi universytet. Zbirnyknaukovykh prats. 247-250. [in Ukrainian].

Skakalskyi, M. Spomyny mynuloho. Kremenchanyna (1962 - 1970). [Memories of the past]. Rukopys [Manuscript]. 314 p. [in Ukrainian].

Rublova, N. \& Rublov, O. (Comps.) (2012). Ukraina - Polshcha 1920 - 1939 rr:: Z istorii dyplomatychnykh vidnosyn USSR z Druhoiu Richchiu Pospolytoiu: Dokumenty i materialy. [Ukraine Poland 1920 - 1939: From the history of diplomatic relations of the USSR with the Second Commonwealth: Documents and materials]. Kyiv: Dukh i litera, 624 p. [in Ukrainian].

Cherkavskyi, M. (1927). Promova senatora M. Cherkavckoho, vyholoshena v senati 02. 03. 1927 r. v zahalnii dyskusii nad derzhavnym biudzhetom. [Senator M. Cherkavsky's speech delivered in the Senate on March 2, 03, 1927 in a general discussion on the state budget]. Lviv: Nakladom V. Tselevycha, 32 p. [in Ukrainian].

Yuzevskyi, H. (2017). Zamist shchodennyka. [Instead of a diary]. (Perekl. Yu. Vaseiko; vstup M. Kucherepy). Lutsk: Vezha-Druk, 168 p. [in Ukrainian].

Yakovenko, N. M. (2000). Pro metodolohiiu doslidzhen serednovichnoi i rannomodernoi istorii Ukrainy. [On the methodology of research on medieval and early modern history of Ukraine]. Naukovi pratsi istorychnoho fakultetu Zaporizkoho derzhavnoho universytet, XI. Retrieved from http://sites.znu. edu.ua/historySciWorks/11/yakovenko.pdf [in Ukrainian].

The article was received on January 18, 2019. Article was recommended for publishing 04.03.2019. 